\title{
DNA-Mediated Gene Transfer
}

National Cancer Institute

\section{Source}

National Cancer Institute. DNA-Mediated Gene Transfer. NCI Thesaurus. Code C19585.

Introduction of naked DNA into cells by various methods. 